\title{
EXPERIMENTAL INVESTIGATION OF CHEMICAL ETCHING ON DIFFERENT MATERIALS USING NITRIC ACID
}

\author{
Savinderjit Singh ${ }^{1}$, Hardeep Singh ${ }^{2}$ \\ ${ }^{1}$ M.Tech student, Dept of Mechanical Engineering, RBU, MOHALI, Punjab, India \\ ${ }^{2}$ Assistant Professor, Dept. of Mechanical Engineering, RBU, MOHALI, Punjab, India
}

\begin{abstract}
In this paper, the experimental work is done on different materials EN5 Steel and EN32 steel. Chemical etching technique is used for this purpose. These both materials are used for the low pressure dies or plastic dies. For the preparing of these dies the complex parts of dies are to be prepared by chemical etching technique. During the machining with chemical etching technique the overcut area of material is caused. In this experimentation minimum overcut area is concluded for best machining. Analysis of variance (ANOVA) is employed to investigate the influence of time, temperature and concentration on minimum overcut area of the material. The experiments was conducted to varying the parameters of etching process like temperature from $18^{\circ} \mathrm{c}$ to $22^{\circ} \mathrm{c}$, Time from 2 hrs to 6 hrs and concentration 8\% to 12\% are studied in details according to Taguchi's design of experiments. At last results are analyzed using Taguchi, ANOVA and parametric optimization is done for minimum overcut area of material. From the experimentation, it is concluded that for etching of EN5 steel and EN32 steel, optimum machining condition for minimum overcut area with Time (2hrs), Temperature (18 c), and Concentration (8\%).
\end{abstract}

Keywords: ANOVA, OVERCUT AREA, TAGUCHI, ETCHING, EN5 STEEL, EN32 STEEL $* * *$

\section{INTRODUCTION}

The main objective of this paper is to study different parameters like time, temperature and concentration (hrs, degree Celsius, percentage) of chemical etching process to develop empirical relationships between different process parameters and out responses namely minimum overcut area of material. In (1981) Pandey PC, Shan HS [1] chemical etching is similar to blanking in sheet metals except material is removed by chemical dissolution rather than by shearing. Used in bur free etching of printed circuit boards, decorative panels etc. In (2007) O Cakir [2] studied chemical etching process had regular metal removal rate, tooling cost of the machining is low, during machining burr formation is very low, the work piece machined by chemical etching process was not subjected by stress introduced by tool material. In (2013) [3] Ravinder Chaudhary studied about the EN32 and EN-5 material is medium strength steel. This material is used in industry to manufacture the rack and pinions, studs bolts, rollers, studs etc. In (2000) H. Sachdev [4] studied about the parameter effects during the etching process. According to the researcher the parameters like temperature, time, concentration can effect on the surface of the material. The MRR of the material was increase with increase in temperature, time and concentration. In (2004) A. Fadaei Tehrani [5] studied about the parameters used in etching process and working on different type of etchants on same one material. During the experiment researcher check the surface roughness of the material when etched the material in different type of solution. In nutshell he selects the etchant which had better MRR and minimum surface roughness on the material.
This necessitates a process optimization to determine optimal values of etching parameters, such as time, temperature and concentration to fully evaluate the performance of etching the materials. The present study is an attempt to achieve this goal when etching EN5 and EN32 Steel.

\section{EXECUTIONS OF EXPERIMENTS}

The ranges of the parameters varied for the experimental work were selected on the basis of results of experiments. The input parameters, which were kept constant during the experimentation, are given below. An experimental optimization is done in calculating the minimum overcut area using these levels.

Table 1: Parameters Available and Used for Experimentation

\begin{tabular}{|l|l|l|l|l|}
\hline \multirow{2}{*}{ S.No } & \multirow{2}{*}{ Parameters } & \multicolumn{4}{|l|}{ Level } \\
\cline { 3 - 5 } & & 1 & 2 & 3 \\
\hline 1 & Time (hrs) & 2 & 4 & 6 \\
\hline 2 & Temprature $\left({ }^{\circ} \mathrm{c}\right)$ & 18 & 20 & 22 \\
\hline 3 & Concentration $(\%)$ & 8 & 10 & 12 \\
\hline
\end{tabular}

Taguchi method, a powerful tool in the design of experiment, is to be used to optimize the etching parameters of effective machining of copper steel. Determine the S/N ratio, and analysis of variance (ANOVA) for indicating the most significant parameters affecting the machining performance criteria, i.e. minimum overcut area of material. 


\section{RESULTS AND DISCUSSIONS EN5 STEEL}

The investigated results of Minimum overcut area obtained during etching process of EN5 steel. The results were obtained at variation of concentration e.g. from $8 \%$ to $12 \%$, temperature e.g. from $18^{\circ} \mathrm{c}$ to $22^{\circ} \mathrm{c}$, and time from $2 \mathrm{hrs}$ to 6 hrs.

\begin{tabular}{r|r|r|r|r|r|} 
& Time & Temprature & concentration & overcut area & SNRA1 \\
\hline $\mathbf{1}$ & 2 & 18 & 8 & 0.61 & 4.2934 \\
\hline $\mathbf{2}$ & 2 & 20 & 10 & 7.00 & -16.9020 \\
\hline $\mathbf{3}$ & 2 & 22 & 12 & 20.15 & -26.0855 \\
\hline $\mathbf{4}$ & 4 & 18 & 10 & 27.60 & -28.8182 \\
\hline $\mathbf{5}$ & 4 & 20 & 12 & 32.54 & -30.2484 \\
\hline $\mathbf{6}$ & 4 & 22 & 8 & 40.64 & -32.1791 \\
\hline $\mathbf{7}$ & 6 & 18 & 12 & 78.40 & -37.8863 \\
\hline $\mathbf{8}$ & 6 & 20 & 8 & 80.00 & -38.0618 \\
\hline $\mathbf{9}$ & 6 & 22 & 10 & 108.60 & -40.7166 \\
\hline
\end{tabular}

Fig 1: Showing the results of etching Parameters on Mean of overcut area on EN5 material

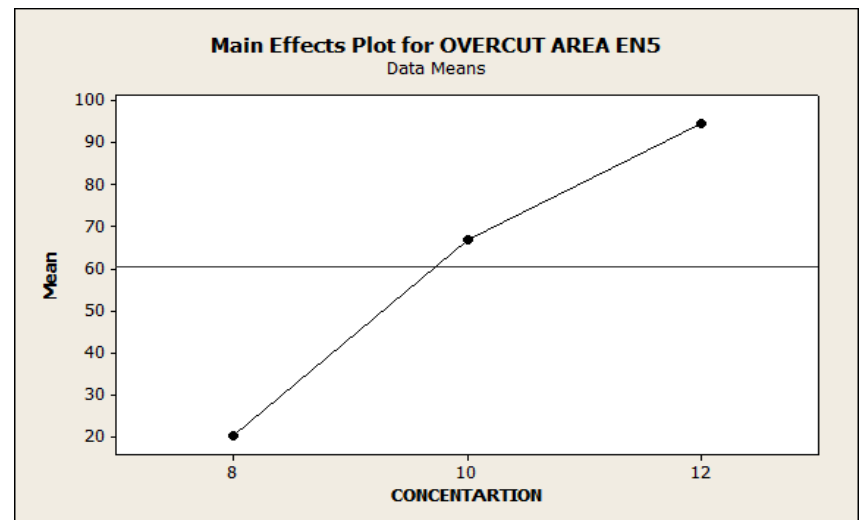

Fig 2: main effects plot for overcut area v/s concentration for EN5 Steel

In Figure 2, here the value of mean overcut area is increased from 20 to 96 when the concentration is increased from $8 \%$ to $12 \%$. Further the mean increases from 20 to 73 when the concentration is increased from $8 \%$ to $10 \%$. The optimum parameter for concentration is $10 \%$.

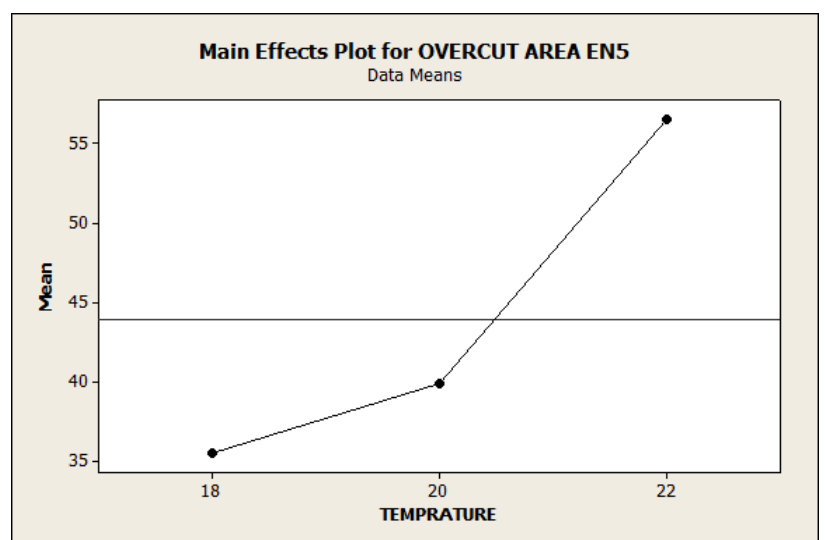

Fig 3 main effects plot for overcut area v/s temperature EN5 steel
In Figure 3, here the value mean effect of overcut area is increased from 36 to 56 when the temperature is increased from $18^{\circ} \mathrm{c}$ to $22^{\circ} \mathrm{c}$. Further the mean of overcut area increases from 36 to 40 when the temperature is increased from $18^{\circ} \mathrm{C}$ to $20^{\circ} \mathrm{c}$. The optimum parameter for current is $20^{\circ} \mathrm{c}$

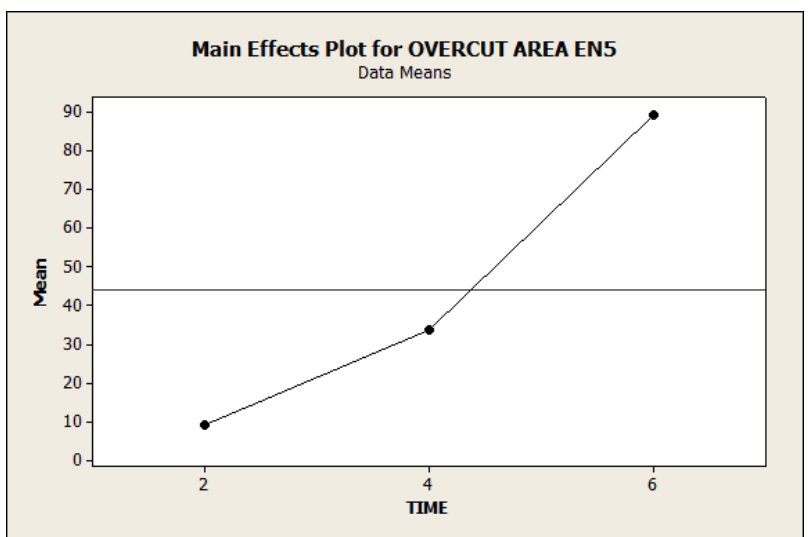

Fig 4 main effects plot for overcut area v/s time EN5 steel

In Figure 4, here the value of mean effect of overcut area is increased from 10 to 90 when the time is increased from 2 hrs to 6 hrs. Further the mean increases from 10 to 32 when the time is increased from $2 \mathrm{hrs}$ to $4 \mathrm{hrs}$. The optimum parameter for current is $4 \mathrm{hrs}$.

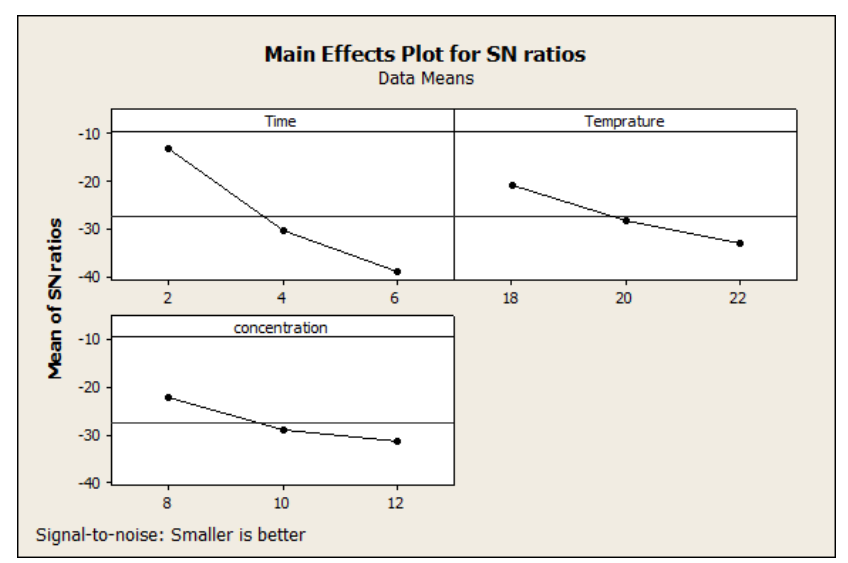

Fig 5 Effect of the Process Parameters on the Mean of S/N ratio.

In Fig 5, mean of $\mathrm{S} / \mathrm{N}$ ratio the maximum value of mean in case of time is at $2 \mathrm{hrs}$, for the temperature maximum value of mean is at $18^{\circ} \mathrm{C}$ and maximum mean value for concentration is $8 \%$. 


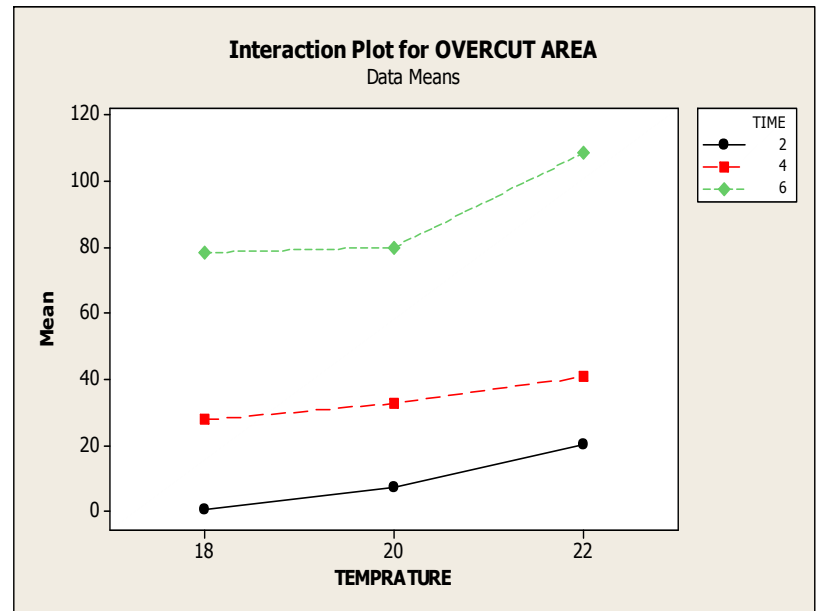

Fig 6 Interaction of Time (hrs) and Temperature $\left({ }^{0} \mathrm{c}\right)$ on overcut area

Fig 6, shows the mean interaction plot of overcut area, time vs. temperature. From this figure it is clear that the value of mean for minimum overcut area is notice at when temperature is $20^{\circ} \mathrm{c}$ at time $2 \mathrm{hrs}$.

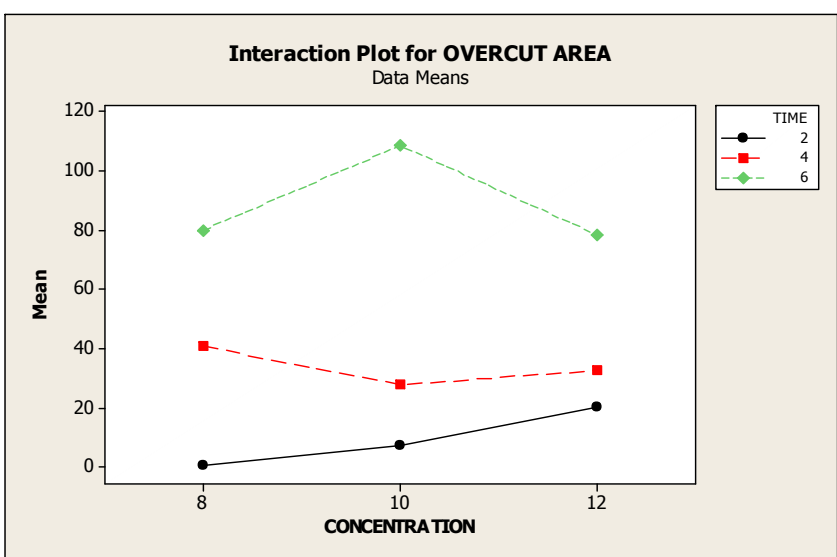

Fig 7 Interaction of Time (hrs) and concentration (\%) on overcut area

Fig 7, shows the mean interaction plot of overcut area, time vs. concentration. From this figure it is clear that the value of mean for minimum overcut area is notice at when time $2 \mathrm{hrs}$ at concentration $8 \%$

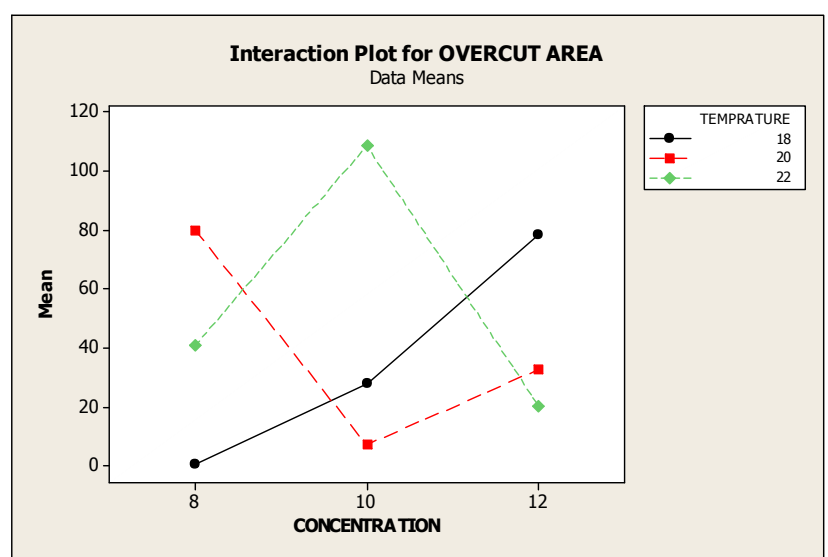

Fig 8 Interaction of concentration $(\%)$ and temperature $\left({ }^{0} \mathrm{c}\right)$ on overcut area
Fig 8, shows the mean interaction plot of overcut area, temperature vs. concentration. From this figure it is clear that the value of mean for minimum overcut area is notice at when temperature is $18^{\circ} \mathrm{c}$ at concentration $8 \%$.

\section{RESULTS AND DISCUSSIONS EN32 STEEL}

The investigated results of Minimum overcut area obtained during etching process of EN32 steel. The results were obtained at variation of concentration e.g. from $8 \%$ to $12 \%$, temperature e.g. from $18^{\circ} \mathrm{c}$ to $22^{\circ} \mathrm{c}$, and time from 2 hrs to 6 hrs.

\begin{tabular}{|c|c|c|c|c|c|}
\hline+ & $\mathrm{C} 1$ & $\mathrm{C} 2$ & $\mathrm{C} 3$ & $\mathrm{C} 4$ & $\mathrm{C} 5$ \\
\hline & TIME & TEMPERATURE & CONCENTRATION & OVERCUT & SNRA1 \\
\hline 1 & 2 & 18 & 8 & 0.41 & 7.7443 \\
\hline 2 & 2 & 20 & 10 & 5.00 & -13.9794 \\
\hline 3 & 2 & 22 & 12 & 17.16 & -24.6903 \\
\hline 4 & 4 & 18 & 10 & 23.70 & -27.4950 \\
\hline 5 & 4 & 20 & 12 & 31.54 & -29.9772 \\
\hline 6 & 4 & 22 & 8 & 39.66 & -31.9671 \\
\hline 7 & 6 & 18 & 12 & 73.42 & -37.3163 \\
\hline 8 & 6 & 20 & 8 & 78.76 & -37.9261 \\
\hline 9 & 6 & 22 & 10 & 103.42 & -40.2921 \\
\hline
\end{tabular}

Fig 9: Showing the results of etching Parameters on Mean of overcut area on EN32 material

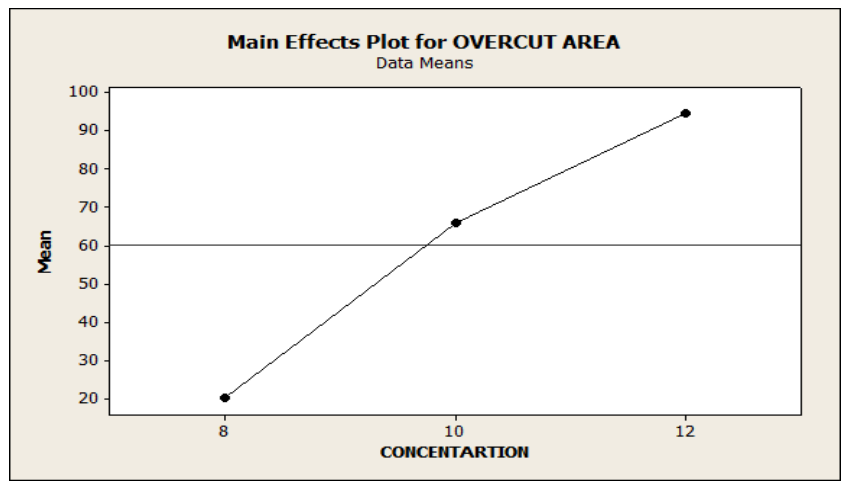

Fig 10: main effects plot for overcut area v/s concentration for EN32 Steel

In Figure 10, here the value of mean overcut area is increased from 20 to 96 when the concentration is increased from $8 \%$ to $12 \%$. Further the mean increases from 20 to 68 when the concentration is increased from $8 \%$ to $10 \%$. The optimum parameter for concentration is $10 \%$.

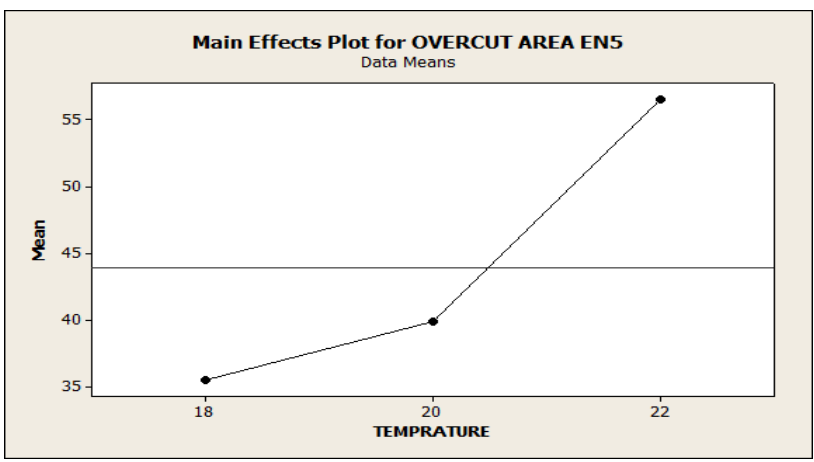

Fig 11 main effects plot for overcut area v/s temperature EN5 steel 
In Figure11, here the value mean effect of overcut area is increased from 36 to 52 when the temperature is increased from $18^{\circ} \mathrm{c}$ to $22^{\circ} \mathrm{c}$. Further the mean of overcut area increases from 36 to 39 when the temperature is increased from $18^{\circ} \mathrm{C}$ to $20^{\circ} \mathrm{c}$. The optimum parameter for current is $20^{0} \mathrm{c}$

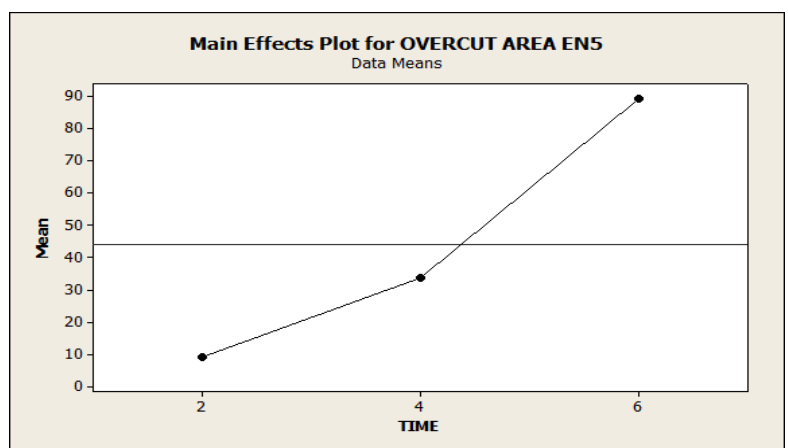

Fig 12 main effects plot for overcut area v/s time EN5 steel

In Figure 12, here the value of mean effect of overcut area is increased from 10 to 90 when the time is increased from $2 \mathrm{hrs}$ to 6 hrs. Further the mean increases from 10 to 32 when the time is increased from $2 \mathrm{hrs}$ to $4 \mathrm{hrs}$. The optimum parameter for current is $4 \mathrm{hrs}$.

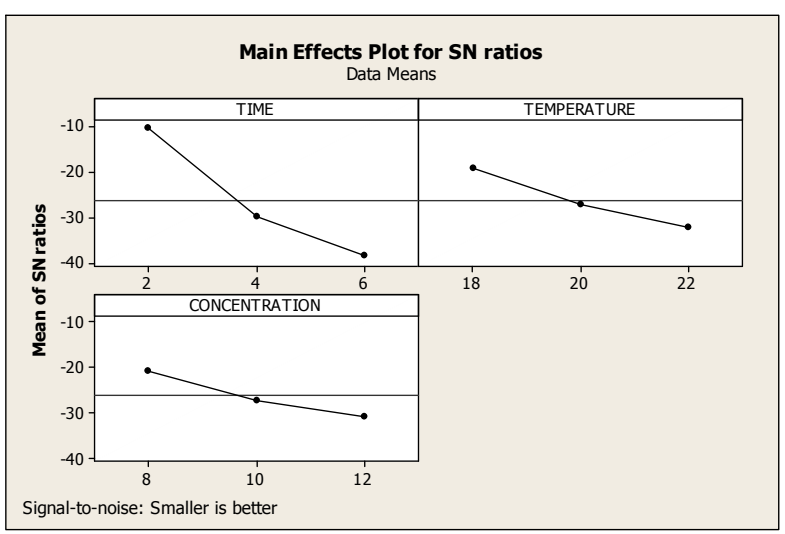

Fig 13 Effect of the Process Parameters on the Mean of S/N ratio

In Fig 13, mean of $\mathrm{S} / \mathrm{N}$ ratio the maximum value of mean in case of time is at $2 \mathrm{hrs}$, for the temperature maximum value of mean is at $18^{\circ} \mathrm{C}$ and maximum mean value for concentration is $8 \%$.

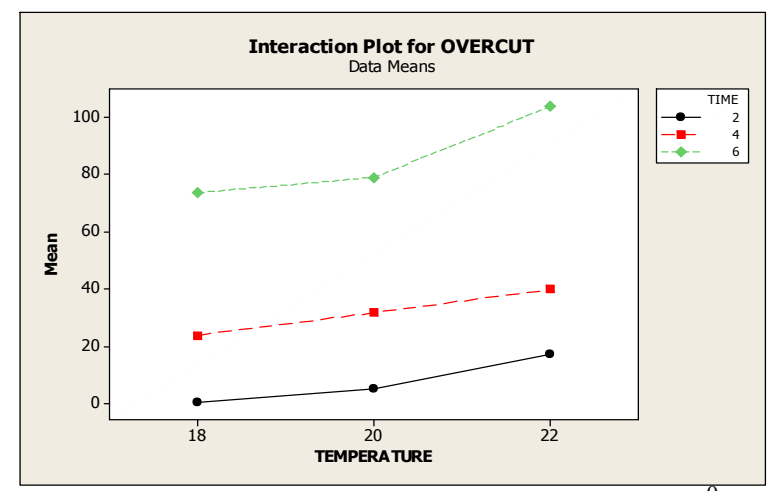

Fig 14 Interaction of Time (hrs) and Temperature $\left({ }^{0} \mathrm{c}\right)$ on overcut area
Fig 14, shows the mean interaction plot of overcut area, time vs. temperature. From this figure it is clear that the value of mean for minimum overcut area is notice at when temperature is $20^{\circ} \mathrm{c}$ at time $2 \mathrm{hrs}$.

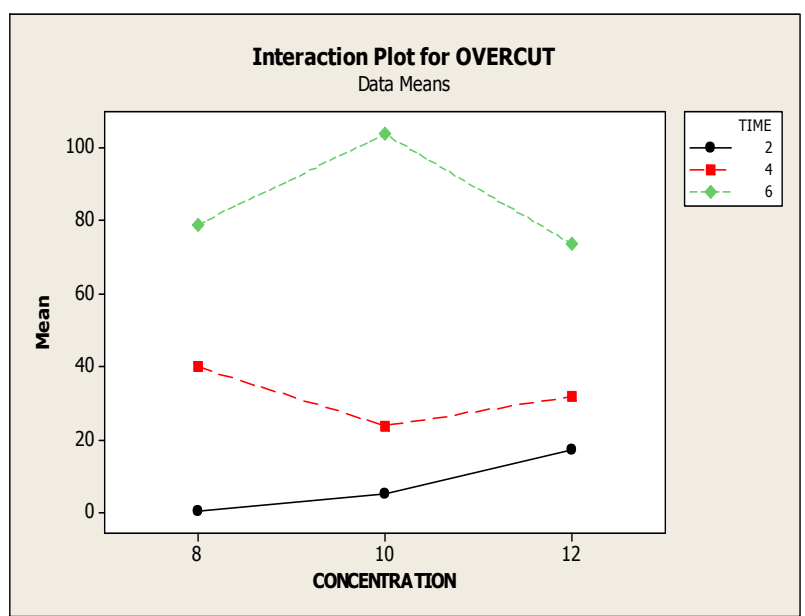

Fig 15 Interaction of Time (hrs) and concentration (\%) on overcut area

Fig 15, shows the mean interaction plot of overcut area, time vs. concentration. From this figure it is clear that the value of mean for minimum overcut area is notice at when time $2 \mathrm{hrs}$ at concentration $8 \%$

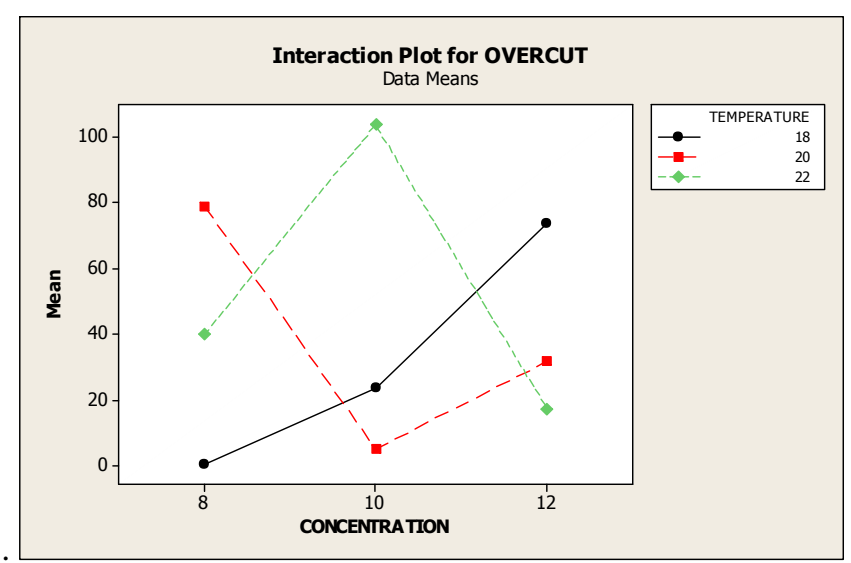

Fig 16 Interaction of concentration $(\%)$ and temperature $\left({ }^{0} \mathrm{c}\right)$ on overcut area

Fig 16, shows the mean interaction plot of overcut area, temperature vs. concentration. From this figure it is clear that the value of mean for minimum overcut area is notice at when temperature is $18^{\circ} \mathrm{c}$ at concentration $8 \%$.

\section{CONCLUSION}

1. It is noted that the minimum value of overcut area is $.61 \mathrm{~mm}^{2}$ and $.41 \mathrm{~mm}^{2}$ which is at $18^{\circ} \mathrm{c}$ temperature, $2 \mathrm{hrs}$ time and $8 \%$ concentration for materials EN5 and EN32.

2. The minimum mean value for minimum overcut area at temperature $18^{\circ} \mathrm{c}$, time $2 \mathrm{hrs}$ and concentration $8 \%$.

3 . The time and concentration are significant factors; temperature is not significant number because its value is 0.168 . 
4. In different interaction plot graphs the optimum values of parameters are $18^{\circ} \mathrm{c}$ temperature, $2 \mathrm{hrs}$ time and $8 \%$ concentration.

5. For EN5 and EN32 material optimum machining condition for minimum overcut area with $18^{\circ} \mathrm{c}$ temperature, $8 \%$ concentration, $2 \mathrm{hrs}$ time.

\section{REFERENCES}

[1]. Pandey PC, Shan HS, Tata Mc Graw Hill education, eBook modern machining processes, (1980)

[2]. O.Çakir, A. Yardimeden, T. Ozben, "chemical machining" archieves of material science and engineering (2007) 499 - 502

[3]. Chaudary Ravinder, Rampal Rohit, Sharma Neeraj "Investigation and Optimization of Materiel Removal Rate for Wire Cut Electro Discharge Machining In EN5 Steel Using Response Surface Methodology" International Journal of Latest Trends in Engineering and Technology (2013) 192- 199

[4]. H. Sachdev, M. Strauß "Selective etching of boron nitride phases" diamond and related materials, (2000) 614619

[5]. A. Fadaei Tehrani, E. Imanian "A new etchant for the chemical machining of St304" journal of material processes technology, (2004) 404-408 